\title{
The new middle class in emerging markets: How values and demographics influence discretionary consumption
}

\author{
Aybegüm G. Belbağ ${ }^{1}$ | M. Mithat Üner ${ }^{2}$ | Erin Cavusgi| ${ }^{3}$ | S. Tamer Cavusgil ${ }^{4,5,6}$ (1)
}

\author{
${ }^{1}$ Department of Business Administration, \\ Faculty of Economics and Administrative \\ Sciences, Bartin University, Bartin, Turkey \\ ${ }^{2}$ School of Business, Atilim University, Ankara, \\ Turkey \\ ${ }^{3}$ School of Management, University of \\ Michigan-Flint, Flint, Michigan \\ ${ }^{4}$ Georgia State University, J. Mack Robinson \\ College of Business, Atlanta, Georgia \\ ${ }^{5}$ University of South Australia Business \\ School, Adelaide, South Australia, Australia \\ ${ }^{6}$ Leeds University Business School, Leeds, \\ West Yorkshire, England \\ Correspondence \\ S. T. Cavusgil, Georgia State University, \\ J. Mack Robinson College of Business, \\ P.O. Box 3989, Atlanta, GA 30302. \\ Email: stcavusgil@gsu.edu
}

The rise of new middle-class consumers in rapidly transforming emerging markets has attracted the attention of Western business executives. What they know about this growing segment of customers will determine whether they succeed or fail in these markets. The present study examines the factors that drive the discretionary consumption of this new middle class, including the effects of consumerist values, religious values, occupation, education levels, and ownership of fixed assets. The study draws its insights from data gathered from 391 new middleclass consumers in Ankara, the second-largest city in Turkey. The findings provide important implications for businesses, both indigenous and foreign. An overall implication is that managers ought to understand and qualify the new middle class in emerging markets not simply by their access to disposable income but by deeper attitudinal and behavioral characteristics.

\section{KEYWORDS}

consumerist values, emerging markets, Iceberg Model, new middle class, religious values, Turkey

\section{1 | INTRODUCTION}

While the concept of middle class goes back several centuries, and middle-class households have always existed in modern societies, the concept of the new middle class is closely linked with the most recent phase of globalization and market liberalization in emerging markets. As such, the new middle class refers to individuals who have joined the ranks of "middle income" consumers in emerging markets since the 1980s-the beginnings of a remarkable transformation in some 25 rapidly developing economies around the world. While members of the new middle class share similarities in terms of purchasing power with the traditional middle class, they tend to be distinct in terms of political attitudes, social habits, and educational achievement.

Globally, it is expected that some 1.6 billion people will join the middle class by 2030 , and this number should increase to 2.6 billion by 2050 , constituting some one-third of the world's population (Ward \& Neumann, 2012). Over the past three decades, new consumer markets flourished in emerging-market economies, with

This article is based on the PhD thesis "The New Middle Class in Turkey: A Study with a Marketing Perspective," completed at Gazi University Institute of Social Sciences, Ankara, Turkey, by Aybegüm Güngördü Belbağ. millions of people joining the global middle class. A rapidly growing and increasingly affluent middle class should generate enhanced demand for consumer goods (Cavusgil, 2013). This group presents new and highly attractive opportunities for Western businesses.

Turkey is a prime example of a rapidly transforming and liberalizing market, and examining its new middle class is instructive. Studies in the Turkish context have so far presented the new middle class as individuals who break their traditional habits and maintain lifestyles and identities that are closely related to consumption (Karademir, 2009).

The purpose of the present study is to examine the effects of consumerist values, religious values, occupational backgrounds, educational achievement, and ownership of fixed assets of the new middle class on their discretionary consumption. Specific research questions are as follows: How does the new middle class identify itself? How are the consumption expenditures of the new middle class aligned? Which consumption groups are discretionary for the new middle class? What are the educational and occupational and asset ownership characteristics of the new middle class? What are the consumerist and religious values of the new middle class? And, finally, how do these characteristics of the new middle class affect their discretionary consumption? 
We seek to contribute to the literature by examining the new middle class in a key emerging market from a multidisciplinary perspective-drawing from disciplines such as sociology, economics, history, and political science. As such, this current study is novel in its examination of a distinct customer group in emerging markets. The remainder of this article is structured as follows. After providing a brief overview of the Turkish context, we clarify the concepts of "middle-class" and "the new middle class." In the following sections, we present our method and then examine the relationships between endogenous and exogenous variables with structural equation modelling. Next, we interpret our findings about the new middle-class consumers in Turkey from a marketing perspective, and we conclude with a discussion of future research topics.

\section{2 | BACKGROUND}

\section{1 | Brief history of Turkish market liberalization}

Emerging markets refer to a subset of former developing countries that have achieved substantial industrialization, modernization, and rapid economic growth since the 1980s (Cavusgil, Knight, \& Riesenberger, 2012), and Turkey is one of them. Most emerging markets are characterized by their growing middle classes, which have seen vast improvements in their life standards and economic situation. The 1980s brought neoliberal policies to Turkey, and the middle class was strengthened thanks to the liberalization efforts of Prime Minister Turgut Ozal, which coincided with a robust new phase of globalization in the world economy. Turkish market liberalization led to a closer economic integration with the global marketplace and, in particular, with the European Union's customs union. Consequently, a consumer culture took root in the country. At the same time, Turkish society experienced the rise of capitalism with strong Islamic undercurrents. Islamic television channels, the Independent Industrialists and Businessmen's Association (MÜSIAD), religious music, green ${ }^{1}$ pop music, and hotels that segregate men and women all emerged during this era. Because of political Islam, a more Islamic middle class began to emerge gradually. Since 2002, the Justice and Development Party (AK Parti) has been in power in Turkey, further promoting Islamic values in commerce and in society. Many businesses catering to this new pious middle class have also sprung up. For example, consumers in Turkey can now make VIP arrangements for pilgrimages to Mecca using one of many new travel agencies.

\subsection{Middle class and the new middle class}

The term middle-class is often defined in economic terms. For example, those who have daily expenditures of $\$ 10-\$ 100$ per person (Kharas, 2010) or those who have an annual income between $\$ 6,000$ and $\$ 30,000$ (Foroohar \& Margolis, 2010). In a rare quantification of middle class in the emerging market, Cavusgil and Kardes (2013a, 2013b) employ two indicators for estimating the size of the middle class in some two dozen emerging markets. Their calculation of the

${ }^{1}$ Green is the holy color of the Islamic faith.
GSU Middle Class Scorecard reflects (a) household disposable income and (b) household expenditures. They further break down the middle class as affluent (upper) middle class (income and expenditure deciles of 7-9) and mass (lower) middle class (income and expenditure deciles of 3-6). Fukuyama (2013) adds education, occupation, and ownership of assets to the key characteristic of the middle classes. Cavusgil and Kardes (2013b) also include values, expectations, and attitudes among the distinctive dimensions of the middle class in emerging markets and suggest the Iceberg metaphor for better understanding of this group.

The concept of the new middle class: Mills (1951) was the first to use the term "new middle-class" in the 1950s by describing this group as white-collar professionals, such as managers; engineers; lawyers; and people who work in education, science and technology, health, and personal care sectors. Market liberalization and reforms in emerging markets, beginning in the 1980s, enabled an increasing number of households to gain a substantial disposable income, which then triggered discretionary consumption. Hence, a new middle class was ushered in, distinct from the traditional middle class. This new middle class in rapidly transforming economies now enjoys disposable income that can be used for discretionary consumption, such as leisure activities, better health care, automobiles, private education for children, and household durables. The new middle class also has an appetite for Western brands, comfort, and lifestyles (Balkan \& Oncu, 2014; Cavusgil, 2013; Cavusgil \& Guercini, 2014; Cavusgil \& Kardes, 2013b; Erdem, 2010; Kravets \& Sandikci, 2014). ${ }^{2}$

The structure of the new middle class in Turkey has altered along with its spread to central Anatolia (Keyman, 2012), along with the big cities of Istanbul, Ankara, and İzmir. The new middle class in Turkey is similar to others in the world; they are generally urbanite, well-educated, white-collar professionals who own a number of assets and are highly engaged in consumption (Ayata, 2007; Balkan \& Oncu, 2014; Erdem, 2010; Erkal, Baloglu, \& Baloglu, 1997; Ipsos KMG, 2012; Karademir, 2009; Keyman, 2012; Kravets \& Sandikci, 2014; Simsek, 2005; Turkishtime Magazine, 2013). What sets them apart from other emerging markets is that the new Turkish middle class possesses both secular and conservative elements (Balkan \& Oncu, 2014; Karademir, 2009; Kravets \& Sandikci, 2014; Sandikci \& Ger, 2007; Ustuner \& Holt, 2010) and are mainly conservative in religious

\footnotetext{
${ }^{2}$ The literature on the middle class is increasingly more prevalent. Sociological works include: Arslan, 2011; Ayata, 2007; Balkan \& Oncu, 2014; Bourdieu, 1984; Erdem, 2010; Goldthorpe, 1987; Harvey, 2005; Karademir, 2009; Karpat, 2009; Keyder, 2013, 2014; Keyman, 2010, 2012, 2014; Kiray, 2005; Kongar, 1999; Marx, 1968; Mills, 1951; Rutz \& Balkan, 2010; Savage et al., 2013; Warner, Meeker, \& Eells, 1949; Weber, 1978 and economic works include (Azevedo \& Atamanov, 2014; Banerjee \& Duflo, 2008; Birdsall, 2010, 2012a, 2012b; Birdsall, Graham, \& Pettinato, 2000; Easterly, 2001; Foroohar \& Margolis, 2010; Kharas, 2010; Kharas \& Gertz, 2010; Lopez-Calva, Rigolini, \& Torche, 2012; Milanovic \& Yitzhaki, 2002; Ravallion, 2009; Ward \& Neumann, 2012). Works representing marketing or business perspectives are relatively limited: Martineau, 1957, 1958; Rich \& Jain, 1968; Cunningham, Russell, \& Cunningham, 1974; Griffin \& Sturdivant, 1973; Coleman, 1983; Oluc, 1987; Williams, 2002; Sandikci \& Ger, 2007; Yılmaz, 2007; Ustuner \& Holt, 2010; Ipsos KMG, 2012; Euromonitor, 2013; Turkishtime Magazine, 2013; Cavusgil, 2013; Cavusgil \& Kardes, 2013a, 2013b; Gao, 2013; Kravets \& Sandikci, 2014; Gouvea, Kapelianis, \& Montoya, 2016; and Uner \& Gungordu, 2016.
} 
terms (Erdem, 2010; Ipsos KMG, 2012; Keyman, 2012; Turkishtime Magazine, 2013; Yılmaz, 2007).

\section{3 | CONCEPTUAL FRAMEWORK: THE ICEBERG MODEL}

The most comprehensive and applicable framework for understanding the new middle classes from a business perspective is the Iceberg Model, proposed by Cavusgil and Kardes (2013a), as shown in Figure 1. The Iceberg Model illustrates that the discretionary consumption by the middle-class consumers is affected by their education, occupation, ownership of assets, values, expectations, and attitudes. Discretionary consumption is made possible with disposable income, which amounts to the income left after taxes and pension savings (Diamond, 2006; Sekulic \& Sibley, 2007). Discretionary consumption can be directed toward the purchase of new products and services, such as automobiles, better health care, and homes.

The Iceberg Model also argues for defining the middle-class consumers in terms of their education, occupation, and ownership of assets. New middle-class individuals tend to have a university degree and prefer to send their children to private schools (Ayata, 2007; Balkan \& Oncu, 2014; Keyder, 2014; Kravets \& Sandikci, 2014; Rutz \& Balkan, 2010). They are also likely to be white-collar professionals (Erdem, 2010; Erkal et al., 1997; Karademir, 2009; Simsek, 2005). Ownership of assets include household appliances, motor vehicles, apartments or homes, and electronic gadgets (Euromonitor, 2013; Ipsos KMG, 2012; Kravets \& Sandikci, 2014; Turkishtime Magazine, 2013; Yılmaz, 2012).

Values, expectations, and attitudes are the deepest invisible part of the Iceberg Model. In the current study, we focus on values-as they are more consistent than attitudes-to define differences and
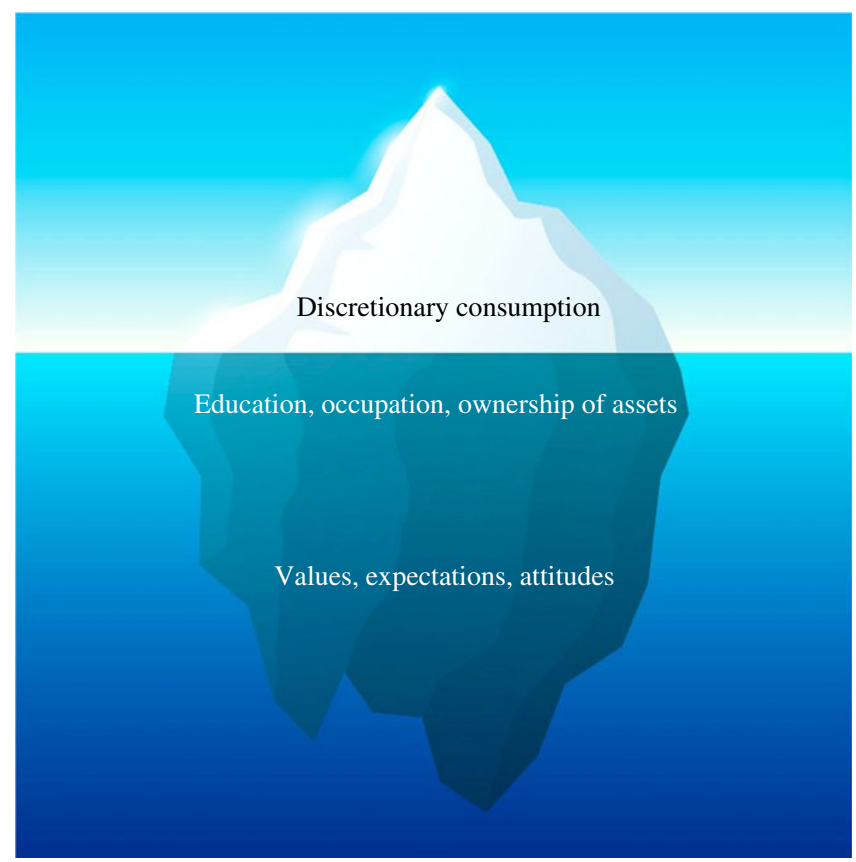

FIGURE 1 Iceberg conceptualization of middle class (adapted from Cavusgil \& Kardes, 2013a, 2013b) similarities among individuals, groups, and cultures. In this context, we examine the consumerist and religious values of the new middle class.

The term "consumerist" reflects newfound preferences for specific products by individuals and purchases that match their individual identities (Paek \& Pan, 2004; Wei \& Pan, 1999). The term is characterized by a preoccupation with the acquisition of consumer goods (Oxford Dictionary, 2017). Consumerism is defined as an active ideology in which the meaning of life is to be found in buying things (Bocock, 2009). Goodwin, Nelson, Ackerman, and Weisskopf (2008) note that some people who have consumerist values find meaning and satisfaction in life by purchasing new consumer goods. This meaning differs from another usage, where consumerism refers to being critical of consumption, or suspicious of goods-as in consumer movements (Ger \& Belk, 1996).

The Consumerist Values scale was developed by Wei and Pan (1999). This scale consists of three dimensions: conspicuous consumption, aspirations for self-fulfillment and indulgence, and reverence (worship) for Western lifestyles. Several studies (Aydın, 2006; Demirezen, 2015; Kravets \& Sandikci, 2014; Odabasi, 2013; Orcan, 2008) indicated that consumption in Turkey has become conspicuous. The concept of conspicuous consumption was also raised by Veblen (2015) and is known as the purchase of goods and services primarily for the purpose of gaining social symbols and status (Wei \& Pan, 1999). Turkish consumers' aspirations for selffulfillment and indulgence are noted in studies such as Kravets and Sandikci (2014), Rutz and Balkan (2010), Demirezen (2015). Aspirations for self-fulfillment and indulgence are related with selfactualization and are defined as the desire to fulfill one's inner self (Wei \& Pan, 1999). The reverence for Western lifestyles by Turkish consumers is highlighted in the studies of Orcan (2008), Arslan (2012), Odabasi (2013), and Kravets and Sandikci (2014), and reflects the consumers' desire for Western and foreign brands over national brands (Wei \& Pan, 1999).

We chose religious values as a distinctive feature of the new middle class in Turkey (Balkan \& Oncu, 2014; Erdem, 2010; Ipsos KMG, 2012; Keyman, 2012; Sandikci \& Ger, 2007; Yılmaz, 2007). Religion is seen as a transmitter of values at a macro level (J.F. Engel, Blackwell, \& Miniard, 1982). Although religiosity is frequently measured with Allport and Ross (1967)'s Religious Orientation scale, which builds on Christianity, this scale is often criticized by scholars. In the current study, we used the scale developed by Rehman and Shabbir (2010)-the Islamic Religiosity Index-to measure the religious values of consumers in our sample. This index is appropriate given the majority of our study subjects are Muslims. Rehman and Shabbir (2010) measure religiosity on five dimensions: ideological, ritualistic, intellectual, consequential, and experimental. The ideological dimension includes the overall beliefs associated with religion, such as beliefs about God, Prophet, fate, etc. The ritualistic dimension includes the actions prescribed by the religion, such as prayer and fasting. The intellectual dimension is a measure of the individuals' knowledge about religion. The consequential dimension measures the importance of the religion, and the experiential dimension describes the feelings associated with religion (Rehman \& Shabbir, 2010). 


\section{4 | HYPOTHESES}

Religiosity and consumerist values: Dimensions of consumerist values like conspicuous consumption, aspirations for self-fulfillment, and indulgence, as well as reverence for Western lifestyles, are at odds with the religion of Islam, which preaches its followers to be modest, to do with less, and not to overindulge in consumption.

Consumerist values and consumption of material goods are closely associated with the identity of the individual and therefore reinforce individualization. Consumerist values tend to enhance materialism. Religious orientation reduces conspicuous consumption (Schwartz, 1992, 1994; Stillman, Fincham, Vohs, Lambert, \& Phillips, 2012). Schwartz $(1992,1994)$ has explored the differences and similarities in human values among cultures and found that selfenhancement values (values such as conspicuous consumption and desire for materialistic goods) and self-transcendence (values that are represented by religion and religiosity) are opposite and contradictory. It is expected that an individual cannot pursue both simultaneously.

Religious symbols are reflected in consumption in two ways. First, religious symbols and values are abstracted from their meaning through the integration with consumer goods, products, and services, such as religious music, green pop, conservative fashion/branding, VIP hajj and umrah tours, etc. Second, individuals who grew up in materialistic societies and internalized consumption habits approach religious beliefs and practices the same way they would consumer products/services. This situation can be seen in cultural and religious tourism and the interpretation of religious texts (Demirezen, 2015). Therefore:

Hypothesis 1 There is a significant negative relationship between religiosity and consumerist values.

Discretionary consumption and religiosity: The Iceberg Model specifies that values are elements that affect discretionary consumption. In the current study, we examine religious and consumerist values. Islamic religion advises its followers not to consume more than needed. Consequently, believers of Islam should theoretically consume fewer discretionary goods and services. Research has previously found that more religious individuals prefer bargain prices and do not consume lavishly (Stillman et al., 2012), although some middle-class Muslims do occasionally enjoy the products of capitalism while remaining loyal to their religion (Bocock, 2009). Therefore, we propose the following:

Hypothesis 2 There is a significant negative relationship between religiosity and discretionary consumption.

Discretionary consumption and consumerist values: Consumerist values consist of three dimensions: conspicuous consumption, aspirations for self-fulfillment and indulgence, and aspiration for Western lifestyles. All three are positively correlated with discretionary consumption. Kravets and Sandikci (2014) refer to the word "comfort" frequently in their study of the new middle classes, which suggests they want a comfortable life, a comfortable income, comfortable attire, and a comfortable consumerist lifestyle. They also point out that new middle-class consumers are exposed to Western lifestyles and brands but may initially balance conspicuous consumption by limiting their purchase of well-known brands (e.g., wearing only a Burberry scarf instead of a full outfit from the same designer). Therefore, we propose the following:

Hypothesis 3 There is a significant positive relationship between consumerist values and discretionary consumption.

Discretionary consumption and occupation, education, and ownership of assets: Based on the Iceberg Model, education, occupation, and ownership of assets have a direct effect on discretionary consumption. To simplify the occupation variable, we made a distinction between public- and private-sector employees. In Turkey, those who choose to work in the public sector tend to be more conservative in relation to those in the private sector. We suspect those working in the public sector may exhibit different discretionary consumption patterns than those working in the private sector. There is some evidence that some prominent individuals in the private sector (e.g., those in entertainment, tourism, or advertising sectors) may influence the lifestyles of the new middle class (Rutz \& Balkan, 2010). Working in the private sector, especially in professions related to marketing and/or sales personnel working in shopping centers, may serve as influential role models. Therefore, we propose the following:

\section{Hypothesis 4 There is a significant negative relationship between working in the public sector and engaging in discretionary consumption.}

Discretionary consumption and education: As the new middle class is better educated than other classes (Ayata, 2007; Balkan \& Oncu, 2014; Keyder, 2014; Kravets \& Sandikci, 2014; Rutz \& Balkan, 2010), educational background may influence discretionary consumption. It is safe to assume that those with higher educational achievement tend to have a broader consumption portfolio and have greater means to afford it. Thus:

Hypothesis 5 There is a significant positive relationship between education and discretionary consumption.

Discretionary consumption and ownership of fixed assets: In Turkey, consumers tend to invest in a house or an automobile before making discretionary expenditures (e.g., luxury items) (Yılmaz, 2007). Thus, the ownership of a house or an automobile provides a degree of financial security to the consumers about their economic future. Therefore, they make discretionary expenditures more comfortably. Thus, we propose the following:

Hypothesis 6 There is a significant positive relationship between ownership of a house and discretionary consumption.

Hypothesis 7 There is a significant positive relationship between ownership of an automobile and discretionary consumption. 
Consumerist values and occupation: Public- versus private-sector employment may affect the consumerist values of individuals. Conspicuous consumption as a consumerist value suggests possessing items that are status symbols. Those in the private sector may engage in conspicuous consumption as a requirement of their profession. On the other hand, the public sector tends to encourage employees to dress more formally and conservatively. Aspirations for self-fulfillment and indulgence relate to conformity, which can be influenced by the type of occupation. Reverence for Western lifestyles mostly indicates purchasing foreign products. Seshadri (2006) cites evidence suggesting occupation correlates with urban consumers' preference to foreign products. Thus:

Hypothesis 8 -There is a significant negative relationship between public-sector occupation and consumerist values.

Consumerist values and ownership of fixed assets: Middle-class consumers value products that serve as status symbols and communicate self-expression (Nonis \& Relyea, 2012). As mentioned previously, consumerist values motivate the ownership of automobiles in emerging markets, which is perceived as a status symbol reflecting the owner's class, wealth, and prestige. Similarly, owning a house, especially in an upscale neighborhood, is a reflection of the owner's class and wealth. Thus:

Hypothesis 9 There is a significant positive relationship between ownership of an automobile and consumerist values.

Hypothesis 10 There is a significant positive relationship between ownership of a house and consumerist values.

Consumerist values and education: Education is an important indicator of the new middle class (Ayata, 2007; Balkan \& Oncu, 2014; Keyder, 2014; Kravets \& Sandikci, 2014; Rutz \& Balkan, 2010). The new middle-class members tend to be more educated than other groups and enjoy greater discretionary consumption. Thus:

Hypothesis 11 There is a significant positive relationship between education and consumerist values.

\section{5 | METHODOLOGY}

\section{1 | Data collection}

\subsection{1 | Study sample}

The study aimed at surveying individuals who would be considered middle-class consumers. Consistent with our conceptualization, we wished to reach well-educated, urban households who appeared to join the middle class over the past several decades, subsequent to the market liberalization reforms, which commenced in the $1980 \mathrm{~s}$. Three districts in Ankara appeared ideal in terms of concentration of the middle-class households: Cankaya, Kecioren, and Yenimahalle. Subjects were chosen from these neighborhoods based on systematic sampling. We conducted face-to-face interviews with study subjects once they agreed to participate. The interviews lasted about 20-30 min, and the interviewer recorded the responses on paper. The final sample consisted of 391 consumers. In terms of income, participants tended to fall into the second, third, and fourth quintiles based on the Turkish Statistical Institute (TUIK) classificationrepresenting middle-income households according to TUIK (2013).

The results of the frequency analysis indicate that the sample is representative of the profile of new middle-class consumers in Turkey. Participants are primarily white-collar professionals, between the age of 25 and 30 (36.6\%), and married (97.4\%). The sample is well-balanced in terms of gender ( $51 \%$ female). Participants consider themselves right wing (26\%) and conservative (38\%); have college degrees (85.4\%); and own a house (50\%), an automobile (54.5\%), and a smartphone (100\%). Typical participants have one child (32.2\%), live in a three-member household (32\%), go on vacation every year (61\%), work in the private sector (69.1\%), and speak English (65.2\%).

\subsection{2 | Measures}

In the current study, discretionary consumption and consumerist values are endogenous variables. Religiosity, occupation, education, and ownership of possessions (ownership of an automobile and a house) are exogenous variables, as they are not affected by the other variables in the model. While education may explain religiosity in some studies (Schuman, 1971; Welch, 1981), we ignored this small effect in the model.

To measure the values in the Iceberg Model, we utilized consumerist values (Paek \& Pan, 2004) and religiosity (Rehman \& Shabbir, 2010) and excluded attitudes and expectations from the model, in favor of simplifying the model. Given that an individual has fewer values than attitudes, using the value concept is a more consistent way to define and explain the differences and similarities between individuals, groups, or cultures (Rokeach, 1968; Long \& Schiffman, 2000; cited by Xiao \& Kim, 2009). The Appendix details the scales used in this study.

\subsection{3 | Data analysis}

We employed PASW Statistics' SPSS 18.0 and IBM AMOS 18.0 for data analysis. First, we carried out a pilot test with 100 responses for reliability concerns. We found that both scales are reliable (Consumerist Values scale, Cronbach's $\alpha=.953$; Islamic Religiosity Index scale, Cronbach's $\alpha=$.935). To identify discretionary consumption groups for our endogenous variable "discretionary consumption," we first obtained a Household Budget Survey micro dataset from the Turkish Statistical Institute. We measured income elasticity with the help of this database and determined the discretionary consumption groups. Second, we carried out exploratory and confirmatory factor analyses for Consumerist Values scale and Islamic Religiosity Index scale. $^{3}$ Third, we analyzed the Pearson correlation analysis,

\footnotetext{
${ }^{3}$ While carrying out exploratory factor analyses, we used Maximum Likelihood and Direct Oblimin Rotation. Eigenvalues greater than 1.0 were considered in the analyses. According to the confirmatory factor analyses, suggested standards for fit indexes such as CMIN/DF must be lesser than and equal to 5 (Marsh \& Hocevar, 1985). An RMSEA lesser than and equal to 0.08 is found acceptable, and if it is between 0.08 and 0.10 , it is found to be mediocre (Byrne, 2010; MacCallum, Widaman, Preacher, \& Hong, 2001). GFI, CFI, and IFI greater than and equal 0.90 are found acceptable (Bentler, 1992; Bollen, 1989; K.S. Engel, Moosbrugger, \& Müller, 2003).
} 
discriminant and convergent validity, composite reliability, and Cronbach's alpha reliability. ${ }^{4}$ Lastly, we carried out structural equation modelling to examine the relationship between endogenous and exogenous variables.

\section{6 | FINDINGS}

\section{1 | Consumer expenditures}

The new middle-class consumers expend their budget on a variety of household needs. These include: food, nonalcoholic drinks, clothing, shoes, transportation, housing and rent, communication, entertainment and culture, tobacco, restaurants and hotels, education, furniture, household appliances, and health care. They tend to save about $10 \%$ of their disposable income. Savings often represent delayed consumption of big-ticket items (e.g., household appliances or furniture) at some point in the future (Boratav, 2005).

\subsection{How do respondents perceive themselves?}

Interestingly, most participants in our study (56.2\%) classify themselves as middle class. Some $29.4 \%$ see themselves as upper middle class in the social hierarchy, and $8.43 \%$ perceive themselves as lower middle class. Finally, some $1.79 \%$ consider themselves as low-income class, and $4.09 \%$ perceive themselves as affluent.

Importantly, participants tend to characterize themselves as having access to some disposable income, confirming that they largely represent the new middle class. They identify themselves as cultured or highbrow, educated, living a comfortable life, having a regular monthly salary, and having a moderate standard of living. They are employed and own a home and automobile. They can afford to dress stylishly, possess a worldview and values, consume branded products, and adhere to religious beliefs. The top three leisure activities of the new middle class tend to be television viewing, visiting shopping centers, and reading books.

\section{3 | Discretionary consumption patterns of respondents}

In the current study, discretionary consumption is an endogenous variable. For identifying discretionary consumption groups, we used the Extended Linear Expenditure System (ELES) (Lluch, 1973). Based on TUIK's (2013) Household Budget Survey database, we estimated income elasticities for the second, third, and fourth income quintiles in Turkey according to the 12 groups. ${ }^{5}$ The ELES is based on "benefit maximization of households" in this system (Saracoglu, Aydogus,

${ }^{4}$ We calculated composite reliability for all dimensions, and these are reliable, as they are greater than 0.70 , suggested by Nunnally and Bernstein (1994). As for convergent validity, AVE values are greater than 0.50 (Bagozzi \& Yi, 1988; Hair, Anderson, Tatham, \& Black, 1998). For discriminant validity, the square root of each variable's AVE value is greater than the correlation of each dimension with other dimensions (Fornell \& Larcker, 1981).

${ }^{5}$ These groups are food and nonalcoholic drinks; alcoholic drinks; cigarettes and tobacco; clothing and shoes; housing and rent; furniture, household appliances and house care services; health; transportation; communication; entertainment and culture; education; restaurants and hotels; and various goods and services.
Kose, \& Isgoren, 2001). We find that the demand for various discretionary consumption groups is sensitive to changes in income (indicating an income elasticity of greater than 1). These include: entertainment and culture; clothing and shoes; furniture, household appliances, and house care services; health care; and transportation. In the present analysis, we focused on the "entertainment and culture" as an indicator of discretionary consumption in order to simplify the model. This category has seen substantial growth among the new middle class. Expenditures on entertainment and culture consist of audiovisual systems; photography; data processing; entertainment and cultural services, such as going out to cinemas or theaters; and purchase of books, newspapers, and stationery (TUIK, 2013).

Ward and Neumann (2012) expect the fastest-growing sectors for the middle class in Turkey to be "leisure time and culture" and "restaurants and hotels." Furthermore, consumption of cultural products and services has served as an effective indicator of belonging to the middle class (see more in Bourdieu, 1984). This is in harmony with our finding that many of our respondents identify themselves as "cultured."

\subsection{Analysis of Consumerist Values and the Islamic Religiosity Index}

We carried out exploratory factor analysis in order to construct the scales for Consumerist Values and the Islamic Religiosity Index. For the Consumerist Values scale, we examined three factors that were found in the original scale ${ }^{6}$ : conspicuous consumption, reverence for Western lifestyles, and aspirations for self-fulfillment and indulgence. For the Islamic Religiosity Index scale, we examined three dimensions: intellectual and consequential, ritualistic, and ideological and experiential. ${ }^{7}$

Subsequent to carrying out exploratory factor analyses, we conducted first- and second-order confirmatory factor analyses for the two scales. Paek and Pan (2004) note that the three components of the Consumerist Values scale can be combined into a single dimension, titled "Westernization," based on the common emphasis on individualism and the high correlation among the three dimensions. The authors indicated that the one-dimensional model has low-fit indices, so they continued with the three-dimensional model in their analysis. Accordingly, we first tested the one-dimensional model for the Consumerist Values scale, but due to the low-fit indices, ${ }^{8}$ we continued the confirmatory factor analysis with three dimensions based on the EFA results. According to the CFA, all parameters are significant at the .05 level $(t>1.96)$. The latent variable "consumerist values" is

${ }^{6}$ For the Consumerist Values scale, $\mathrm{KMO}$ is greater than 0.7 , and Bartlett's test of Sphericity is significant, which means the dataset is appropriate for factor analysis (explained variance: 63.600, KMO: 0.910, Bartlett's test of Sphericity approximate chi-square: 6050.789 , df: $210, p=0.00$ ). Factor loadings vary between 0.45 and 0.98 .

${ }^{7}$ According to the Islamic Religiosity Index scale, $\mathrm{KMO}$ is greater than 0.7, and Bartlett's test of Sphericity is significant (explained variance: 63.236, KMO: 0.896, Bartlett's test of Sphericity approximate chi-square: 5540.668 , df: $190, p=0.00$ ). Factor loadings vary between 0.42 and 0.92 .

${ }^{8} \mathrm{CMIN}=2259.933 ; \mathrm{CMIN} / \mathrm{DF}=16.74 ; \mathrm{RMSEA}=0.2 ; \mathrm{GFI}=0.507$. 
TABLE 1 Pearson correlation results, reliability analysis, AVE, CR, and mean

\begin{tabular}{|c|c|c|c|c|c|c|c|c|c|c|c|}
\hline & SELF & WEST & CONS & RIT & INCON & IDEX & EC & $\mathrm{OH}$ & OA & $\mathbf{E}$ & 0 \\
\hline SELF & 1 & & & & & & & & & & \\
\hline WEST & $.183 * *$ & 1 & & & & & & & & & \\
\hline RIT & $-.124 *$ & $-.265 * *$ & $-.148 * *$ & 1 & & & & & & & \\
\hline INCON & .027 & $-.108 *$ & -.033 & $.442 * *$ & 1 & & & & & & \\
\hline $\mathrm{OH}$ & .089 & -.022 & -.049 & .021 & -.091 & -.002 & $.245^{* *}$ & 1 & & & \\
\hline OA & .077 & .091 & $.182 * *$ & .054 & -.030 & -.037 & $.215^{* * *}$ & $.295^{* *}$ & 1 & & \\
\hline$E$ & -.027 & $.105 *$ & .005 & $-.151 * *$ & $-.121 *$ & -.057 & -.001 & $-.099 *$ & $-.180 * *$ & 1 & \\
\hline $\mathrm{O}$ & $-.136 * *$ & $-.119 *$ & $-.102 *$ & $.157^{* *}$ & $.266^{* *}$ & $.233^{* *}$ & $-.157 * *$ & -.034 & -.014 & $-.104 *$ & 1 \\
\hline Mean & 4.08 & 2.69 & 3.04 & 3.40 & 4.39 & 4.39 & - & - & - & - & - \\
\hline
\end{tabular}

$\mathrm{AVE}$ = average variance extracted; CONS = conspicuous consumption; $\mathrm{CR}=$ composite reliability; $\mathrm{EC}=$ entertainment and culture; $\mathrm{E}=$ education; IDEX = ideological and experimental; INCON = intellectual and consequential; $\mathrm{O}=$ occupation; $\mathrm{OA}=$ ownership of an automobile; $\mathrm{OH}=$ ownership of a house; RIT = ritualistic; SELF = self-fulfillment and indulgence; WEST = reverence for Western lifestyles. $* p<.05, * * p<.01$.

best explained by the "self-fulfillment and indulgence" item $\left(R^{2}=0.46\right)$. Fit indices suggest the model is acceptable. ${ }^{9}$ We also carried out a second-order factor analysis for the Consumerist Values scale. All results are significant at the .05 level $(t>1.96)$, and the fit indices are acceptable. ${ }^{10}$

For the first-order confirmatory factor analysis of the Islamic Religiosity Index scale, we first employed a one-factor model with the Islamic Religiosity Index scale and found the fit indices to be low. ${ }^{11}$ Hence, we continued our analysis with the three-dimensional model per the EFA analysis, which resulted in acceptable fit indices. ${ }^{12}$ We also carried out a second-order factor analysis for the Islamic Religiosity Index scale. The latent variable "religious values" is best explained by the "ideological and experiential" variable $\left(R^{2}=0.85\right)$. All results are significant at the .05 level $(t>1.96)$, and the fit indices are acceptable. ${ }^{13}$ Final versions of the Consumerist Values and Islamic Religiosity Index scales can be found in the Appendix.

Finally, we carried out a reliability analysis, a Pearson correlation analysis, and convergent and discriminant validity analysis. These

${ }^{9}$ Items 33, 41, and 46 were removed from the analysis as they loaded on more than one factor. Items 37,42 , and 57 are reference variables. For improving fit indices, we made a modification between the errors of item 44 and items 45, 52, and 53. Standardized regression weights vary between 0.552 and 0.953. Fit indices are: $\mathrm{CMIN}(p=0.00)=338.406, \mathrm{CMIN} /(\mathrm{DF}=87)=3.890$, RMSEA $=0.086, \mathrm{NFI}=0.928, \mathrm{CFI}=0.945, \mathrm{GFI}=0.896, \mathrm{AGFI}=0.857$, and $\mathrm{IFI}=0.946$

${ }^{10}$ Fit indices are: $\mathrm{CMIN}(p=0.00)=339.257, \mathrm{CMIN} /(\mathrm{DF}=87)=3.900$, RMSEA $=0.086, \mathrm{NFI}=0.928, \mathrm{CFI}=0.945, \mathrm{GFI}=0.895, \mathrm{AGFI}=0.856$, and $\mathrm{IFI}=0.945$

${ }^{11} \mathrm{CMIN} / \mathrm{DF}=11.908, \mathrm{RMSEA}=0.167$, and $\mathrm{GFI}=0.641$.

${ }^{12}$ We excluded items $63,64,71,73,74$, and 78 as they loaded on more than one factor. Items 62, 67, and 75 are reference variables. All of the results are significant at the 0.05 level $(t>1.96)$, and the fit indices are acceptable (CMIN/ $[\mathrm{DF}=41]=4.023 ; \mathrm{RMSEA}=0.088 ; \mathrm{NFI}=0.936 ; \mathrm{CFI}=0.951 ; \mathrm{GFI}=0.928$; $\mathrm{AGFI}=0.884$; and $\mathrm{IFI}=0.951$ ). Standardized regression weights vary between 0.672 and 0.918

${ }^{13}$ Fit indices are: $\mathrm{CMIN} /(\mathrm{DF}=41)=4.023, \mathrm{RMSEA}=0.088, \mathrm{NFI}=0.936$, $\mathrm{CFI}=0.951, \mathrm{GFI}=0.928, \mathrm{AGFI}=0.884$, and $\mathrm{IFI}=0.951$. tests confirm both scales are reliable and valid. The results are presented in Table 1.

\section{5 $\mid$ Results of the structural equations modeling}

With the structural equations modeling (SEM) analysis, we first tested the significance of paths and removed nonsignificant paths. The final research model as well as the causality relationships between variables and fit indices are shown in Table 2. All results are significant at the .05 level $(t>1.96)$, and the fit indices are acceptable.

Based on the SEM analysis, the following hypotheses are confirmed: $\mathrm{H} 1, \mathrm{H} 3, \mathrm{H} 4, \mathrm{H} 6, \mathrm{H}$, and $\mathrm{H}$ 9. The following hypotheses are rejected: $\mathrm{H} 2, \mathrm{H} 5, \mathrm{H} 8, \mathrm{H} 10$, and $\mathrm{H} 11$. Discretionary consumption is represented by entertainment and cultural expenditures in the model. Our revised research model based on the SEM analysis is depicted in Figure 2.

As per the SEM, when religious values (REL) increase by $1 S D$, consumerist values (CONSUMERIST) are reduced by 0.174 SD. Owning an automobile (coded as: $1=$ yes $0=$ no) raises the average of consumerist values by 0.219 SD. Owning a house (coded as: $1=$ yes, $0=$ no) decreases the average of consumerist values by 0.115 versus not owning a house. The most effective exogenous variable on consumerist values is the ownership of an automobile (standardized $\beta=0.219$ ). Both religious values (standardized $\beta=-0.174$ ) and ownership of a house (standardized $\beta=-0.115$ ) have a significant but negative effect on consumerist values.

Furthermore, when consumerist values are increased by $1 S D$, the entertainment and culture $(\mathrm{EC})$ variable-our proxy for discretionary consumption-is increased by 0.115 SD. Owning an automobile (coded as: $1=$ yes $0=$ no) raises the average of entertainment and culture expenditures by $0.130 S D$ versus not owning an automobile. Owning a house (coded as: $1=$ yes, $0=$ no) increases the average of entertainment and culture expenditures by 0.207 SD versus not owning a house. When it comes to occupation (coded as: $1=$ public 
TABLE 2 Structural equations modeling results

\begin{tabular}{|c|c|c|c|c|c|c|}
\hline Path & & & Standardized regression weights & SE & $t$ & $p$ \\
\hline Consumerist values & $<---$ & Religious values & -.174 & .032 & -2.683 & .007 \\
\hline Consumerist values & $<---$ & Ownership of an automobile & .219 & .032 & 3.380 & $* * *$ \\
\hline Consumerist values & $<---$ & Ownership of a house & -.115 & .028 & -2.006 & .045 \\
\hline Conspicuous consumption & $<---$ & Consumerist values & .934 & .608 & 6.183 & $* * *$ \\
\hline Entertainment and culture & $<---$ & Consumerist values & .115 & .614 & 2.094 & .036 \\
\hline Entertainment and culture & $<---$ & Ownership of an automobile & .130 & .287 & 2.546 & .011 \\
\hline Entertainment and culture & $<---$ & Occupation & -.135 & .285 & -2.820 & .005 \\
\hline Self-fulfillment and indulgence & $<---$ & Consumerist values & .328 & & & \\
\hline Reverence for Western lifestyles & $<---$ & Consumerist values & .690 & .608 & 6.183 & $* * *$ \\
\hline Entertainment and culture & $<---$ & Ownership of a house & .207 & .277 & 4.116 & $* * *$ \\
\hline Ideological and experimental & $<---$ & Religious values & .833 & .117 & 11.340 & $* * *$ \\
\hline Intellectual and consequential & $<---$ & Religious values & .739 & & & \\
\hline Ritualistic & $<---$ & Religious values & .608 & .158 & 10.433 & $* * *$ \\
\hline
\end{tabular}

$\mathrm{CMIN} /(\mathrm{DF}=27)=2.77, \mathrm{RMSEA}=0.067, \mathrm{NFI}=0.903, \mathrm{CFI}=0.934, \mathrm{GFI}=0.965, \mathrm{AGFI}=0.928, \mathrm{IFI}=0.936 . * * * p<.001$.

sector, $0=$ private sector), a public-sector employee's average of entertainment and culture expenditures is reduced by $0.135 \mathrm{SD}$, compared to someone working in the private sector.

The most effective exogenous variable on entertainment and culture expenditures is the ownership of a house (standardized $\beta=0.207$ ). The others include occupation (standardized $\beta=-0.135$ ), ownership of an automobile (standardized $\beta=0.130$ ), and consumerist values (standardized $\beta=0.115$ ).

In summary, consumerist values, ownership of a house, and ownership of an automobile all have significant positive effects on discretionary consumption as operationalized by entertainment and cultural expenditures. When it comes to occupation, working in the public sector has a significant negative effect on entertainment and cultural expenditures. Religious values do not have a significant effect on entertainment and culture expenditures. Nevertheless, they have a negative effect on consumerist values. Furthermore, ownership of an automobile has a significant positive relationship and ownership of a house has a significant negative relationship with consumerist values.

\section{7 | DISCUSSION}

About one-third of the population in Turkey now belongs to the middle class (Cavusgil, Knight, \& Riesenberger, 2014). Given their possession of a substantial disposable income, they have energized the economy and have attracted numerous foreign companies to do business in the country. Yet to develop effective marketing strategies for this market segment, companies first need to understand these consumers' behavioral characteristics and consumption patterns. In this

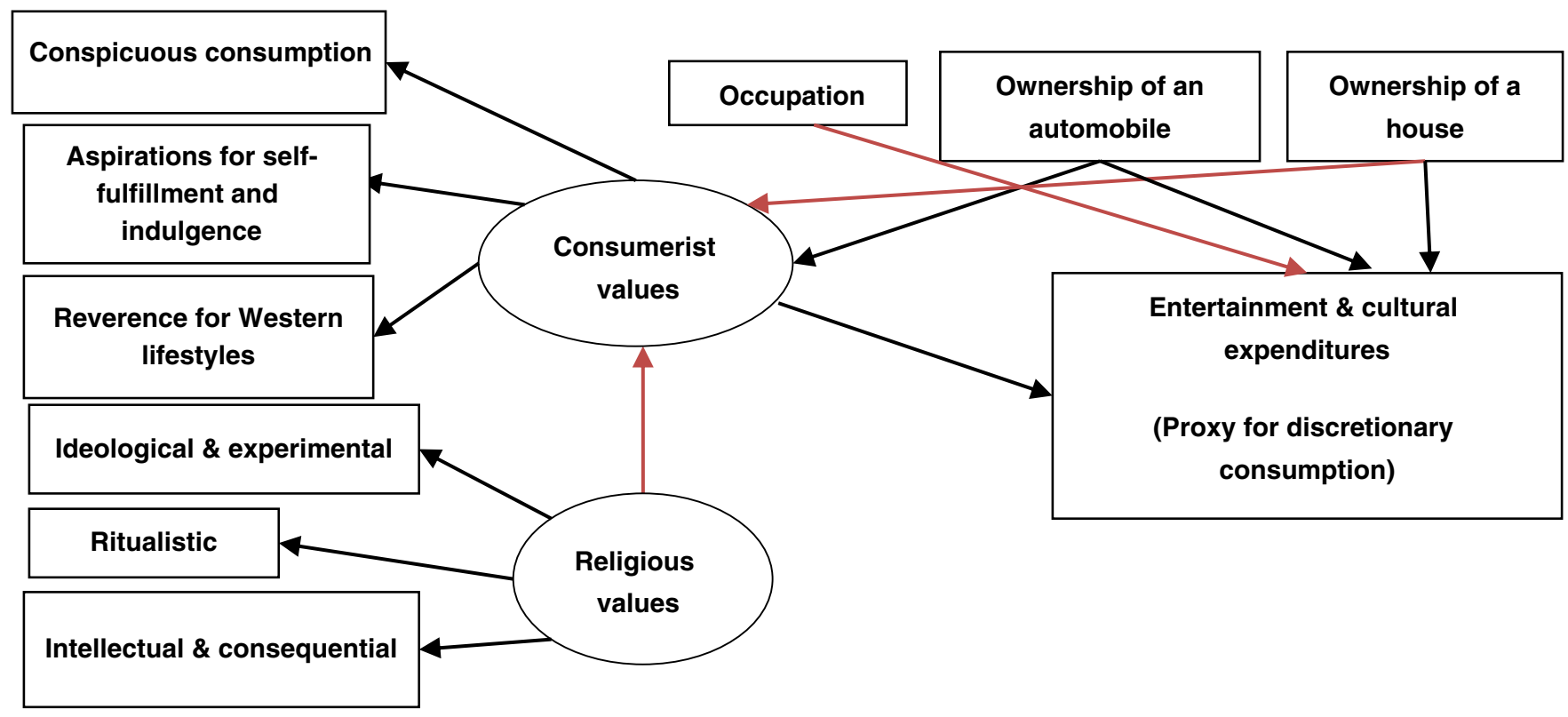

$\longrightarrow$ Denotes significant negative relationship

FIGURE 2 Revised research model 
study, we examined the factors that drive the discretionary consumption of the new middle class, including the effects of consumerist values, religious values, occupation, educational background, and ownership of fixed assets.

Consistent with the findings of previous studies of the middle class in Turkey (Cavusgil \& Kardes, 2013a; Kravets \& Sandikci, 2014; Uner \& Gungordu, 2016), we find that the middle class is well represented in large, urban areas. They tend to be well educated and possess white-collar jobs, and many speak English. A typical middle-class consumer has a single child, lives in a three-member household, owns an apartment and an automobile, and goes on vacation every year, including foreign travel. On average, they save about $10 \%$ of their household income and spend the highest percentage of their income on food and nonalcoholic drinks. They see clothing and shoes, entertainment and culture, furniture, health, and transportation as discretionary consumption. Self-fulfillment or indulgence is a reflection of their consumerist values. Our empirical findings indeed reveal a strong link between consumerist or material values and discretionary consumption, as measured by expenditures for entertainment and cultural activities.

One of the most interesting findings of the study is the negative relationship between religious values and consumerist values. It is generally expected that consumers become more materialistic and individualistic through economic growth. Thus, we confirm that consumerist values are interlaced with individualism and materialism and have a significant negative relationship with religious values.

What is surprising, however, is that we did not find a statistically significant relationship between religious values and discretionary consumption. In a dominantly religious country such as Turkey, we expected this relationship to be negative. Yet our study shows that religious values do not have a direct effect on entertainment and cultural expenditures. Why? One plausible explanation is that, in the contemporary society, materialistic consumption and strong religious values have become more compatible. The modern, urban consumer may have found new justification for being a devout religious person and may engage in materialistic consumption simultaneously.

Indeed, there is some evidence that supports this explanation in the Turkish context. It has been suggested that the internal negotiation process of the religious classes can allow a person to be both modern and Muslim, to a degree (Ozbolat, 2014). As such, they feel uninhibited when it comes to conspicuous consumption and feel free to participate in social activities and entertainment. Thus, consumption is legitimized even in the presence of strong religious codes.

Another interesting finding is the weak but statistically significant negative relationship between religious and consumerist values (Table 2, path coefficient $=-0.174$ ). Contributing to this relationship is the new environment we find in Turkey and other emerging markets. Widespread use of media, dominance of advertising and commercials, and shopping in modern malls featuring merchandise and fashion from the West have all transformed the emerging markets into consumerist societies. In Turkey, this new environment has led religion to be integrated into the system of commodities (Demirezen, 2015). Viewing religion as a commodity creates a weak negative relationship between religiosity and consumerist values for the new middle-class consumers. The internal negotiation process described earlier also allows consumers to justify this apparent contradiction between religious values and consumerism. As such, the consumption ideology is transferred to cultural and religious codes in the context of identity construction, and consumption is legitimized (Ozbolat, 2014).

The previously mentioned findings point to an interesting contradiction in the Turkish context. While the Turkish society identifies closely with religion and acknowledges that religion affects consumption, ultimately, this is not reflected in their actual consumption habits. This is an important implication for Western businesses.

What are, then, the key determinants of discretionary consumption? Statistical analysis reveals the following factors to be prominent influences on entertainment and cultural consumption (proxy for discretionary consumption): reverence for Western lifestyles, aspirations for self-fulfillment and indulgence, and conspicuous consumption. It appears that the new middle class values having a choice of products and services to purchase, appreciates symbolic values represented in their consumption, and strives to build its identity. This may be their way of accessing happiness through discretionary consumption.

Is there a hierarchy or natural order in terms of discretionary consumption by the new middle class? Finding that the ownership of an apartment and an automobile enhances the likelihood of discretionary consumption is very revealing. From other studies, we know the ownership of a home and a personal vehicle is highly treasured among the new middle class. In fact, Cavusgil and Kardes (2013a) find the most significant commonality of all emerging-market households is that they all identify the ownership of an automobile as a sign of "having arrived." Our finding that the ownership of such fixed assets serves as a facilitator of cultural and entertainment consumption is very much in harmony with the literature. It may be argued that the new middle class may postpone its consumption of cultural products and services only after these fixed assets (home and automobile) have been secured.

What about the effects of occupation on discretionary consumption? Our results suggest working in the public sector is negatively associated with discretionary consumption. This finding may be explained with the widely accepted image of public-sector workers-so-called civil servants. Recognizable even from their strictly standard (and dull) attire, public-sector employees may be more restrained in their discretionary consumption. When it comes to consumption of cultural products, they may be even more conservative. Most public enterprises do not necessarily promote entertainment and cultural activities.

A final interesting finding relates to the contradictory effects of owning a home versus an automobile on consumerist values. Ownership of a home is negatively associated with consumerist values, whereas owning an automobile is positively associated with consumerist values. Why?

One explanation may lie in the nature of how these two competing expenditures are traditionally viewed among Turkish families. An apartment or a home is certainly a much more expensive asset a family would own in its lifetime. Middle-class households typically perceive home ownership as an investment, as well as a valuable gift to pass on to their heirs. A home provides confidence, an economic insurance to its owner that can create an illusion he/she is actually moving up to a higher class. In contrast, automobiles typically serve as status symbols and a signal to his/her social circles that he/she "has now arrived." 


\section{8 | MANAGERIAL IMPLICATIONS}

The study findings provide important implications for businesses, both indigenous and foreign. Naturally, given their stepped-up consumption patterns, middle-class consumers represent the prime targets for any marketer. An overall implication is that managers ought to understand and qualify the new middle class in emerging markets not simply by their access to disposable income but deeper attitudinal and behavioral characteristics. Recalling the Iceberg metaphor, defining the new middle class only in terms of their new spending capacity and consumption would provide only an incomplete understanding. A more comprehensive understanding of how and why the new middle-class consumer expends his/her newly acquired disposable income is possible only by delving into their complex aspirations, value systems, and demographics. This conclusion suggests a more thoughtful, research-based approach to delineating and targeting consumers. Marketers can no longer afford to segment markets by demographics alone.

Second, to reach the new middle-class consumers, marketers need to employ a variety of social networks given their attraction to Western lifestyles and shared experiences, which, in turn, lead to self-fulfillment. As an example, they can offer discounts, free tickets, or gift cards, or run other types of promotions to consumers who are willing to share their story and insights about their experiences with a product or brand. In this context, social media is a powerful tool for reaching middle-class consumers. Although it was not a planned aspect of our interviews, research suggested the new middle-class consumers are ardent users of social media. Interestingly, a considerable portion of their purchases has also shifted to online shopping.

Third, businesses ought to personalize marketing efforts. Consumers are attracted to brands that allow them to express their individuality, especially as it relates to culture and entertainment. Brand ambassadors could further help this effort by telling stories that appeal to different categories of consumers. It is interesting to observe how many new fashion consultants have emerged in recent years, influencing their followers with advice on brands ranging from shoes to apparel.

Fourth, firms may develop mobile applications where cultural and entertainment experiences can be shared. For example, the Istanbul City Guide app can ask personal questions about one's age, gender, education, nationality, budget, companions, food preferences, hobbies, and the duration of visit in order to make individualized recommendations to the visitor. Given the widespread use of mobile devices and availability of internet connections, marketers are advised to develop such applications in order to create a loyal following.

Finally, customization of experiences is a powerful marketing tool a marketer has at his/her disposal in order to attract and please the new middle-class consumer. In the contemporary marketplace, those businesses that can tell a good story, either directly or through the use of third-party advocates, are likely to gain a superior competitive advantage. Increasingly, the new middle-class consumers are searching for consumption experiences rather than simply products or services.

\section{9 | LIMITATIONS AND SUGGESTIONS FOR FUTURE RESEARCH}

Naturally, the study was limited to a single country and only to three districts in a single city in Turkey. Furthermore, only the adult members of the new middle class were surveyed in the study, without any comparison to members of the lower- and upper-income classes. Therefore, the generalizability of the research findings is a limitation. It would be highly desirable to contrast our findings with those of other emerging markets such as Brazil, Mexico, and South Korea.

The current study explored the effects of materialistic and religious values on discretionary consumption. Future research can examine other attitudinal, social, and behavioral determinants of middle-class consumption. Similarly, discretionary consumption was operationalized in a single expenditure category in our studyentertainment and cultural expenditures. Scholars ought to employ other categories of discretionary consumption. These can include interesting sectors such as credit card usage, demand for halal food, demand for daycare and recreational centers, need for dental services, and applications for passports.

Finally, future scholarly work can benefit from the use of different data-collection methods, variables and their operationalization, and varied data analysis techniques. For example, in-depth interviews with the members of the new middle class may produce deeper insights explaining discretionary consumption. It is hoped that the present study and its findings will motivate other scholars to examine this important phenomenon.

\section{ORCID}

S. Tamer Cavusgil (D) https://orcid.org/0000-0003-1947-492X

\section{REFERENCES}

Allport, G. W., \& Ross, J. M. (1967). Personal religious orientation and prejudice. Journal of Personality and Social Psychology, 5(4), 432-443.

Arslan, Z. (2011). Urban Middle Class, Lifestyle and Taste in Kecioren and Cankaya, Ankara: Distinction through Home Furniture and, Furnishing and Decoration. (PhD dissertation). Middle East Technical University, Ankara.

Arslan, Z. (2012). Geçmişten Bugüne Eleştirel Bir Orta Sınıf Değerlendirmesi. Toplum ve Demokrasi, 6(13-14), 55-92.

Ayata, S. (2007). Meydandakiler Yeni Orta Sinıftır (The people in the events are from the new middle class). Retrieved from http://www.milliyet. com.tr/2007/05/21/siyaset/asiy.html

Aydın, K. (2006). Social stratification and consumption patterns in Turkey. Social Indicators Research, 75, 463-501.

Azevedo, J. P., \& Atamanov, A. (2014). Pathways to the middle class in Turkey: How have reducing poverty and boosting shared prosperity helped? (World Bank Policy Research Working Paper, No. 6834), Washington, DC, US: The World Bank.

Bagozzi, R. P., \& Yi, Y. (1988). On the evaluation of structural equation models. Journal of the Academy of Marketing Science, 16(1), 74-94.

Balkan, E., \& Oncu, A. (2014). "İslami Orta Sınıfın Yeniden Üretimi". Neoliberalizm, İslamcı Sermayenin Yükselişi ve AKP kitabı içerisinde, Hazırlayanlar: Neşecan Balkan, Erol Balkan, Ahmet Öncü (pp. 251-290). İstanbul: Yordam Kitap.

Banerjee, A. V., \& Duflo, E. (2008). What is middle class about the middle classes around the world? Journal of Economic Perspectives, 22(2), 3-28.

Bentler, P. M. (1992). On the fit of models to covariances and methodology to the bulletin. Psychological Bulletin, 112, 400-404. 
Birdsall, N. (2010). The (indispensable) middle class in developing countries; or, the rich and the rest, not the poor and the rest (Center for Global Development Working Paper 207) (pp. 1-36) Washington, DC, US: Center for Global Development.

Birdsall, N. (2012a). A note on the middle class in Latin America (Center for Global Development Working Paper 303) (pp. 1-23) Washington, DC, US: Center for Global Development.

Birdsall, N. (2012b). Oops: Economists in confused search for the middle class in the developing world. Retrieved from http://www.cgdev.org/ blog/

oops-economists-confused-search-middle-class-developing-world

Birdsall, N., Graham, C., \& Pettinato, S. (2000). Stuck in the tunnel: Is globalization muddling the middle class? (Center on Social and Economic Dynamics Working Paper No. 14) (pp. 1-36), Luxembourg: LIS Cross-National Data Center.

Bocock, R. (2009). Tüketim (Consumption). Ankara, Turkey: Dost Kitabevi.

Bollen, K. A. (1989). A new incremental fit index for general structural equation models. Sociological Methods \& Research, 17, 303-316.

Boratav, K. (2005). 1980'li Yıllarda Türkiye'de Sosyal Sinıflar ve Bölüşüm (ikinci Baskı). İstanbul, Turkey: İmge Kitabevi.

Bourdieu, P. (1984). Distinction: A social critique of the judgement of taste (Çev. Richard nice). Abingdon, England: Routledge Classics.

Byrne, B. M. (2010). Structural equation modeling with AMOS basic concepts application and programming (2nd ed.). New York, US: Routledge Taylor and Francis Group.

Cavusgil, T. (2013). Middle class phenomenon in emerging markets: Multi-disciplinary \& multi country perspectives, 1st Middle Class Phenomenon in Emerging Markets Conference. Atlanta, GA: Georgia State University J. Mack Robinson College of Business.

Cavusgil, T., \& Guercini, S. (2014). Trends in middle class as a driver for strategic marketing. Mercati e Competitiva, no. 3, pp. 7-10.

Cavusgil, T., \& Kardes, i. (2013a). Quantifying the size of middle class in emerging markets: GSU-CIBER Middle Class Scorecard, $1^{\text {st }}$ Middle Class Phenomenon in Emerging Markets Conference, Atlanta, GA: Georgia State University J. Mack Robinson College of Business.

Cavusgil, T., \& Kardes, í. (2013b). Brazil: Rapid development, internationalization, and middle-class formation. Revista Eletrônica De Negócios Internacionais, 8(1, Art.1), 1-16.

Cavusgil, T., Knight, G., \& Riesenberger, J. H. (2012). International business: New realities (2nd ed.). New York, NY: Pearson Prentice Hall.

Cavusgil, T., Knight, G., \& Riesenberger, J. H. (2014). International business the new realities (3rd ed.). New York, NY: Pearson Prentice Hall.

Coleman, R. P. (1983). The continuing significance of social class to marketing. Journal of Consumer Research, 10, 265-280.

Cunningham, W. H., Russell, M. M., \& Cunningham, C. M. (1974). Urban markets in industrializing countries. Journal of Marketing, 38(2), 2-12.

Demirezen, ì. (2015). Tüketim Toplumu ve Din. İstanbul, Turkey: Değerler Eğitimi Merkezi.

Diamond, E. (2006). Fashion retailing: A multi-channel approach. Upper Saddle River, NJ: Pearson Education.

Easterly, W. (2001). The middle-class consensus and economic development. Journal of Economic Growth, 6(4), 317-355.

Engel, J. F., Blackwell, R. D., \& Miniard, P. (1982). Consumer behavior. New York, NY: Dryden Press.

Engel, K. S., Moosbrugger, H., \& Müller, H. (2003). Evaluating the fit of structural equation models: Tests of significance and descriptive goodness-of-fit measures. Methods of Psychological Research, 8(2), 23-74.

Erdem, T. (2010). Türkiye'de Modernleşme ve Demokratikleşmenin Bir İzdüşümü olarak Yeni Orta Sınıf, Erol Güngör'ün Anısına Türkiye'de Değişim Sempozyumu, ss. 285-304.

Erkal, M. E., Baloglu, B., \& Baloglu, F. (1997). Ansiklopedik Sosyoloji Sözlüğ̈̈. İstanbul, Turkey: Der Yayınları.

Euromonitor International Consumer Survey (2013). Middle class home, in Reaching the emerging middle classes beyond BRIC, UK: Euromonitor International.

Fornell, C., \& Larcker, D. F. (1981). Evaluating structural equation models with unobservable variables and measurement error. Journal of Marketing Research, 18(1), 39-50.
Foroohar, R., \& Margolis, M. (2010, March 15). The scary new rich: Global middle class is more unstable and less liberal than we thought. Newsweek, pp 20-23.

Fukuyama, F. (2013). The middle class revolution. Europe edition: Wall Street Journal. Retrieved from http://online.wsj.com/news/articles/ SB10001424127 887323873904578571472700348086

Gao, M. H. (2013). Culture determines business models: Analyzing Home Depot's failure case in China for international retailers from a communication perspective. Thunderbird International Business Review, 55(2), 173-191.

Ger, G., \& Belk, R. W. (1996). I'd like to buy the world a Coke: Consumptionscapes of the "less affluent world." Journal of Consumer Policy, 19(3), 271-304.

Goldthorpe, J. H. (1987). Social mobility and class structure in modern Britain. Oxford, England: Clarendon Press.

Goodwin, N., Nelson, J. A., Ackerman, F., \& Weisskopf, T. (2008). Consumption and the consumer society, A GDAE Teaching Module on Social and Environmental Issues in Economics, excerpt from Microeconomics in Context. Medford, MA, USA: Tufts University. Retrieved from http:// ase.tufts.edu/gdae/education_materials/modules/consumption_and_ the_consumer_society.pdf

Gouvea, R., Kapelianis, D., \& Montoya, M. (2016). Marketing challenges and opportunities in emerging economies: A Brazilian perspective. Thunderbird International Business Review, 60(2), 193-205.

Griffin, W. D., \& Sturdivant, F. D. (1973). Discrimination and middle-class minority consumers. Journal of Marketing, 37(3), 65-68.

Hair, J. F., Jr., Anderson, R. E., Tatham, R. L., \& Black, W. C. (1998). Multivariate data analysis. Upper Saddle River, NJ: Prentice-Hall.

Harvey, D. (2005). A brief history of neoliberalism. Oxford, England: Oxford University Press.

Ipsos KMG. (2012). "Türkiye'yi Anlama Kılavuzu." Turkey: Ipsos KMG. Retrieved from http://www.turkiyeyianlamakilavuzu.com/Turkiyeyi_ Anlama_Kilavuzu_EKitap.pdf

Karademir, I. (2009). Different facets of new middle classness: A case study in the city of Ankara (Master thesis). Middle East Technical University.

Karpat, K. H. (2009). Türkiye'de Laiklik Perdesi Altında İktidar Kavgası Var (There is a fight for power behind the curtain of secularism in Turkey). Turkey: Sabah Newspaper. Retrieved from http://www.sabah.com.tr/ Gundem/2009/06/15/turkiyede_laiklik_perdesi_altinda_iktidar_ kavgasi_var

Keyder, C. (2013). İstanbul Küresel ile Yerel Arasında. İstanbul, Turkey: Metis Yayınları.

Keyder, C. (2014). "Yeni Orta Sınıfa Dikkat." Retrieved from http://www. taraf.com.tr/haber-yeni-orta-sinifa-dikkat-157992/

Keyman, F. (2010). Türkiye'de üç orta sınıf kavga ediyor (Three middle classes quarrel in Turkey). Retrieved from http://www.taraf.com.tr/ yazilar/nese-duzel/fuat-keyman-turkiyede-uc-orta-sinif-kavga-ediyor/9923/

Keyman, F. (2012). Türkiye'nin Geleceğini Orta Sınıf Belirleyecek (Middle class will determine the future of Turkey). TÜsiAD Görüş Dergisi, 76, 23-27.

Keyman, F. (2014). 30 Mart Sonrası Yeni Türkiye, Kutuplaşma ve Demokrasi, Görüş Dergisi, TÜSIAD, Nisan 2014, No. 83, pp. 57-63.

Kharas, H. (2010). The emerging middle class in developing countries (OECD Development Centre Working Paper No. 285) pp. 1-61.

Kharas, H., \& Gertz, G. (2010). The new global middle class: A cross-over from west to east. Washington, D.C., US: Wolfensohn Center for Development.

Kiray, M. B. (2005). Tüketim Normları Üzerine Karşılaştırmalı Bir Araştırma. İstanbul, Turkey: Bağlam Yayıncllık.

Kongar, E. (1999). 21. Yüzyılda Türkiye 2000'li Yıllarda Türkiye'nin Toplumsal Yapısı. İstanbul, Turkey: Remzi Kitabevi.

Kravets, O., \& Sandikci, O. (2014). Competently ordinary: New middle-class consumers in the emerging markets. Journal of Marketing, 78(4), 125-140.

Lluch, C. (1973). The extended linear expenditure system. European Economic Review, 4, 21-32.

Long, M., \& Schiffman, L. G. (2000). Consumption values and relationship: Segmenting the market for frequency programs. Journal of Consumer Marketing, 17(3), 214-232.

Lopez-Calva, L. F., Rigolini, J., \& Torche, F. (2012). Is there such thing as middle-class values? Class differences, values and political orientations in 
Latin America (Working Paper, Discussion Paper series, Forschungsinstitut zur Zukunft der Arbeit, No. 6292).

MacCallum, R. C., Widaman, K. F., Preacher, K. J., \& Hong, S. (2001). Sample size in factor analysis: The role of model error. Multivariate Behavioral Research, 36(4), 611-637.

Marsh, H. W., \& Hocevar, D. (1985). An application of confirmatory factor analyses to the study of self-concept: First and higher order factor models and their invariance across groups. Psychological Bulletin, 97(3), 562-582.

Martineau, P. (1957). The pattern of social classes, Proceedings of the American Marketing Association, 233-247.

Martineau, P. (1958). Social classes and spending behavior. Journal of Marketing, 23(2), 121-130.

Marx, K. (1968). Theories of surplus value. Part 2. Moskova: Progress.

Milanovic, B., \& Yitzhaki, S. (2002). Decomposing world income distribution: Does the world have a middle class? Review of Income and Wealth, 48(2), 155-178.

Mills, C. W. (1951). White collar: The American middle classes. Oxford, England: Oxford University Press.

Nonis, S. A., \& Relyea, C. (2012). Business innovations from emerging market countries into developed countries: Implications for multinationals from developed countries. Thunderbird International Business Review, 54(3), 291-298.

Nunnally, J. C., \& Bernstein, I. H. (1994). Psychometric theory (3rd ed.). New York, NY: McGraw-Hill.

Odabasi, Y. (2013). Tüketim Kültürü Yetinen Toplumdan Tüketen Topluma. İstanbul. Turkey: Sistem Yayıncılık.

Oluc, M. (1987). Sosyal sınıflar (sosyal katmanların) pazarlama açısından önemi. İstanbul, Turkey: Pazarlama Dünyası.

Orcan, M. (2008). Osmanlı'dan Günümüze Modern Türk Tüketim Kültürü (ikinci Baskı). Ankara, Turkey: Harf Eğitim Yayıncılığı.

Oxford Dictionary. (2017). https://en.oxforddictionaries.com/definition/ consumerist

Ozbolat, A. (2014), Tüketim Bağlamında Dindarlığın Dönüşümü. Retrieved from http://www.birikimdergisi.com/guncel/tuketim-baglamindadindarligin-donusumu

Paek, H. J., \& Pan, Z. (2004). Spreading global consumerism: Effects of mass media and advertising on consumerist values in China. Mass Communication and Society, 7, 491-515.

Ravallion, M. (2009). The developing world's bulging (but vulnerable) middle class (Policy Research Working Paper, No. 4816) (pp. 1-30). Washington, DC, US: The World Bank.

Rehman, A., \& Shabbir, M. S. (2010). The relationship between religiosity and new product adoption. Journal of Islamic Marketing, 1(1), 63-69.

Rich, S. U., \& Jain, S. C. (1968). Social class and life cycle as predictors of shopping behavior. Journal of Marketing Research, 5, 41-49.

Rokeach, M. J. (1968). A theory of organization and change within value-attitude systems. Journal of Social Issues, 24, 13-22.

Rutz, H. J., \& Balkan, E. M. (2010). Reproducing class education, neoliberalism and the rise of the new middle class in Istanbul. Oxford, England: Berghahn Books.

Sandikci, O., \& Ger, G. (2007). Constructing and representing the Islamic consumer in Turkey. Fashion Theory, 11(2/3), 189-210.

Saracoglu, B., Aydogus, O., Kose, N., \& Isgoren, D. (2001). Türkiye'de Su Ürünleri Sektörü: Üretim, Talep ve Pazarlama, Proje Raporu 2001-19, Ankara. Journal of Marketing, 23(2), 120-130.

Savage, M., Devine, F., Cunningham, N., Taylor, M., Yaojun, L., Hjellbrekke, J., ... Miles, A. (2013). A new model of social class? Findings from the BBC's great class survey experiment, Sociology, 47(2), (pp. 1-32).

Schuman, H. (1971). The religious factor in Detroit: Review, replication, and reanalysis. American Sociological Review, 36, 30-48.

Schwartz, S. H. (1992). Universals in the content and structure of values: Theoretical advances and empirical tests in 20 countries. In M. Zanna (Ed.), Advances in experimental social psychology. 1-65, San Diego, CA: Academic Press.

Schwartz, S. H. (1994). Beyond individualism/collectivism: New dimensions of values. In U. Kim, H. C. Triandis, C. Kagitcibasi, S. C. Choi, G. Yoon (Eds.), Individualism and collectivism: Theory application and methods (pp. 85-119). Newbury Park, CA: Sage.
Sekulic, A., \& Sibley, N. (2007). Understanding the affluent consumers of china. New York, US: MasterCard Worldwide Insights.

Seshadri, V. (2006). Consumerism: With reference to selected home appliances. New Delhi, India: Mittal Publications.

Simsek, A. (2005). Yeni Orta Sınıf. Ankara, Turkey: L\&M Yayınları.

Stillman, T. F., Fincham, F. D., Vohs, K. D., Lambert, N. M., \& Phillips, C. A. (2012). The material and immaterial in conflict: Spirituality reduces conspicuous consumption. Journal of Economic Psychology, 33, 1-7.

TUIK (2013). Turkish Statistical Institute Household Budget Survey Microdata Set. Retrieved from https://biruni.tuik.gov.tr/yayin/views/ visitorPages/english/index.zul.

Turkishtime Magazine (2013). Orta Sınıfın Yükselişi, Ekim sayısı.

Uner, M. M., \& Gungordu, A. (2016). The new middle class in Turkey: A qualitative study in a dynamic economy. International Business Review, 25(3), 668-678.

Ustuner, T., \& Holt, D. (2010). Toward a theory of status consumption in less industrialized countries. Journal of Consumer Research, 37(1), 37-56.

Veblen, T. B. (2015). Aylak Sınıfin Teorisi Kurumların iktisadi Incelemesi, Translated by: Eren Kırmızıaltın. Ankara, Turkey: Heretik Basın Yayın.

Ward, K., \& Neumann, F. (2012). The consumer in 2050: The rise of the EM middle class, HSBC Global Research.

Warner, W. L., Meeker, M., \& Eells, K. (1949). Social class in America; a manual of procedure for the measurement of social status. Oxford, England: Science Research Associates.

Weber, M. (1978). Economy and society: An outline of interpretive sociology. Berkeley, CA, US: University of California Press.

Wei, R., \& Pan, Z. (1999). Mass media and consumerist values in the People's Republic of China. International Journal of Public Opinion Research, 11(1), 75-96.

Welch, K. W. (1981). An interpersonal influence model of traditional religious commitment. The Sociological Quarterly, 22(1), 81-92.

Williams, T. G. (2002). Social class influences on purchase evaluation criteria. Journal of Consumer Marketing, 19, 249-276.

Xiao, G. E., \& Kim, J. O. (2009). The investigation of Chinese consumer values, consumption values, life satisfaction and consumption behaviors. Psychology and Marketing, 26(7), 610-624.

Yılmaz, H. (2007). Türkiye'de orta sınıfı tanımlamak, Açık Toplum Vakfı ve Boğaziçi Üniversitesi. Retrieved from http://www.osiaf.org.tr/images/ basin/pdf/OSI_OrtaSinif_Sunus.pdf

Yılmaz, H. (2012). Türkiye'de orta sınıfı tanımlamak, Açık Toplum Vakfı ve Boğaziçi Üniversitesi. Retrieved from http://www.aciktoplumvakfi.org. $\mathrm{tr} / \mathrm{pdf} / \mathrm{muhafazakarlik/05.pdf}$

\section{AUTHORS' BIOGRAPHIES}

Aybegüm G. Belbağ (agungordu@bartin.edu.tr) is an assistant professor at Bartin University. She specializes in the sociology of consumption and international marketing. She is interested in subjects such as materialism, gift-giving, middle classes, globalization, cosmopolitanism, ethnocentrism, and animosity. She has authored more than 20 national and international indexed articles.

M. Mithat Üner (mithat.uner@atilim.edu.tr) currently serves as the dean and a full-time professor at Atilim University. Previously, he served as a professor and dean at Gazi University in Ankara. His areas of expertise include: international marketing, services marketing, tourism marketing, and e-commerce. He is an author of more than 50 articles with some 400 citations. He is an author of two books in Turkey, one of which is Marketing, Born-Global Businesses in Turkey. He has also edited the book Business Administration. He serves on the review boards of various journals. 
Erin Cavusgil (erinc@umflint.edu) is an associate professor at the University of Michigan-Flint. She holds a BS in chemical engineering from the University of Michigan, an MS in biomedical Engineering from the University of Minnesota, and a PhD in marketing from Michigan State University. She spent 3.5 years working in the pharmaceutical industry as a chemical engineer. Her main research interests include new product development and international marketing. Her research has been published in the Journal of Product Innovation Management, the Journal of Academy of Marketing Sciences, International Business Review, and the Journal of Business Research, among others.

S. Tamer Cavusgil (stcavusgil@gsu.edu) currently serves as executive director of the Center for International Business Education and Research (CIBER), and Fuller E. Callaway Professorial Chair at Georgia State University. He is also a visiting professor at Leeds University Business School and the University of South Australia Business School. He specializes in the internationalization of the firm, global strategy, emerging markets, and buyerseller relationships in cross-border business. Author of more than 200 refereed journal articles, $\mathrm{He}$ is also the senior author of the leading textbook, International Business: The New Realities, with G. Knight and J. Riesenberger (fourth ed., 2017, Pearson). His work is among the most cited contributions in international business. Google citations indicate over 34,000 citations as of early 2018 (h-index of 80). He is the founding editor of the Journal of International Marketing and the annual book series Advances in International Marketing. Most recently, he serves as the editor-inchief of Rutgers Business Review.
How to cite this article: Belbağ AG, Üner MM, Cavusgil E, Cavusgil ST. The new middle class in emerging markets: How values and demographics influence discretionary consumption. Thunderbird Int. Bus. Rev. 2019;61:325-337. https://doi. org/10.1002/tie.21980

\section{APPENDIX. FINAL SCALES USED IN THE STUDY}

\begin{tabular}{|c|c|}
\hline \multicolumn{2}{|c|}{ Item no. Item } \\
\hline \multicolumn{2}{|c|}{ Islamic Religiosity Index scale } \\
\hline \multicolumn{2}{|c|}{ Intellectual and consequential } \\
\hline 75 & I try to avoid activity that hurts others. \\
\hline 76 & I always try to help those who need my help. \\
\hline 77 & I try to be honest and fair with others. \\
\hline 70 & $\begin{array}{l}\text { I always keep myself earning through haram } \\
\text { (prohibited) means. }\end{array}$ \\
\hline 72 & $\begin{array}{l}\text { I know the basic and necessary knowledge about } \\
\text { my religion. }\end{array}$ \\
\hline \multicolumn{2}{|l|}{ Ritualistic } \\
\hline 67 & I regularly recite the Holy Quran. \\
\hline 65 & I regularly offer prayer five times a day. \\
\hline 66 & I fast regularly during Ramadan. \\
\hline \multicolumn{2}{|c|}{ Ideological and experimental } \\
\hline 62 & $\begin{array}{l}\text { I have firm belief in all basic ideological } \\
\text { dimensions of Islam. }\end{array}$ \\
\hline 81 & $\begin{array}{l}\text { I have a feeling of being punished by Allah for } \\
\text { doing something wrong. }\end{array}$ \\
\hline 82 & $\begin{array}{l}\text { I feel pleasure by seeing others following Islamic } \\
\text { teaching. }\end{array}$ \\
\hline \multicolumn{2}{|c|}{ Consumerist Values scale } \\
\hline \multicolumn{2}{|c|}{ Conspicuous consumption } \\
\hline 37 & Stylish dresses give me a great deal of pleasure. \\
\hline 34 & $\begin{array}{l}\text { I take pleasure in trying new and fashionable } \\
\text { products. }\end{array}$ \\
\hline 36 & I prefer fashionable to practical outfits. \\
\hline 38 & Fancy and distinctive living is attractive to me. \\
\hline 39 & I pay close attention to trends in fashion. \\
\hline 40 & I enjoy trying the latest hairstyles. \\
\hline 35 & The way I dress is a reflection of my personality. \\
\hline \multicolumn{2}{|c|}{ Reverence for Western lifestyles } \\
\hline 52 & $\begin{array}{l}\text { Although they are expensive, I prefer Western } \\
\text { products. }\end{array}$ \\
\hline 53 & Western products give me a lot of satisfaction. \\
\hline 51 & I prefer Western culture and arts. \\
\hline 50 & I desire a lifestyle modeled on the West. \\
\hline \multicolumn{2}{|c|}{ Aspirations for self-fulfillment and indulgence } \\
\hline 42 & Life means taking on risks and challenges. \\
\hline 43 & $\begin{array}{l}\text { I have great expectations of what I can } \\
\text { accomplish. }\end{array}$ \\
\hline 44 & I want to lead my life in my own way. \\
\hline 45 & Pleasure comes from what I enjoy doing. \\
\hline
\end{tabular}

